\title{
Ultrasound Cavitation Versus Cryolipolysis on Central Obese Patients
}

\author{
AMR N.A. ABOTALEB, M.Sc.*; AKRAM A. SAYED, Ph.D.**; HEBA A. ABDEEN, Ph.D.** and \\ MARRY W. FAWZY, M.D.*** \\ The Department of Physical Therapy for Cardiovascular/Respiratory Disorders and Geriatrics, Faculty of Physical Therapy, \\ 6th of October* and Cairo** Universities and the Department of Internal Medicine, Faculty of Medicine, Cairo University***, \\ Egypt
}

\begin{abstract}
Background: Central Obesity is one of the most common worldwide diseases afflicting humans. It is a major health problem throughout the world because of its high prevalence and its association with increased risk of cardiovascular and liver diseases.
\end{abstract}

Aim of the Study: Was to determine the effect of ultrasound cavitation versus cryolipolysis on central obese patients.

Subjects: Thirty (30) patients of both sexes, 15 men and 15 women. They were assigned into two groups equal in number. Their ages ranged from 45 to 55 years. Group A with mean age (50.47 \pm 3.31$)$ years and Group B with mean age $(49.47 \pm 3.89)$ years.

Methods: Body Mass Index (BMI), Waist Circumference (WC) and abdominal fat percentage was measured before and after performing ultrasound cavitation and cryolipolysis sessions in both groups. Group A patients received ultrasound cavitation sessions for one month ( 8 sessions/patient), Group $\mathrm{B}$ patients received cryolipolysis sessions for one month (one session/patient).

Results: The results revealed that there was statistically significant reduction in central obesity (BMI, abdominal fat $\%$ and WC) in both Group A and Group B. But there wasn't statistically significant reduction in central obesity (BMI, abdominal fat $\%$ and $\mathrm{WC}$ ) between two groups. There was improvement in Group B than Group A. In Group A, the percentage of improvement for BMI, abdominal fat $\%$ and WC was $2.94 \% \downarrow, 11.07 \% \downarrow$ and $5.59 \% \downarrow$, respectively. In Group B, the percentage of improvement for BMI, abdominal fat $\%$ and $\mathrm{WC}$ was $3.62 \% \downarrow, 19.11 \% \downarrow$ and $4.68 \% \downarrow$ respectively.

Conclusion: There was improvement in central obesity after applying ultrasound cavitation and cryolipolysis sessions with mild better results in cryolipolysis than ultrasound cavitation.

Correspondence to: Dr. Amr N.A. Abotaleb,

The Department of Physical Therapy for Cardiovascular/ Respiratory Disorders and Geriatrics, Faculty of Physical Therapy, $6^{\text {th }}$ of October University, Egypt
Key Words: Central obesity - Ultrasound cavitation - Cryolipolysis.

\section{Introduction}

CENTRAL obesity, is when excessive abdominal fat around the stomach and abdomen has built up to the extent that it is likely to have a negative impact on health. There is a strong correlation between central obesity and cardiovascular disease [1]

The immediate cause of obesity is net energy imbalance, the organism consumes more usable calories than it expends, wastes, or discards through elimination. Some studies indicate that visceral adiposity, together with lipid deregulation and decreased insulin sensitivity, is related to the excessive consumption of fructose. Greater meat consumption has also been positively associated with greater weight gain, and specifically abdominal obesity. Other environmental factors, such as maternal smoking, estrogenic compounds in the diet, and endocrine-disrupting chemicals may be important also [2] .

Abdominal fat is composed of several distinct anatomic depots: Subcutaneous fat, which can be divided into anterior and posterior or superficial and deep layers, and intra-abdominal fat, which

\footnotetext{
Abbreviations:

BMI : Body Mass Index.

WC : Waist Circumference.

AF\% : Abdominal Fat percentage.

WHR: Waist Hip Ratio.

BFP : Body Fat Percentage

UC : Ultrasonic Cavitation.

HIFU : High Intensity Focused Ultrasound.

Cryo : Cryolipolysis.
} 
can be divided into intra-peritoneal and retroperitoneal sites. Intra-peritoneal fat, also known as visceral fat [3]

A newer explanation of lipotoxicity that unlike subcutaneous fat, visceral fat cells release their metabolic products directly into the portal circulation, which carries blood straight to the liver. As a result, visceral fat cells that are enlarged and stuffed with excess triglycerides pour free fatty acids into the liver. Free fatty acids also accumulate in the pancreas, heart, and other organs. In all these locations, the free fatty acids accumulate in cells that are not engineered to store fat. The result is organ dysfunction, which produces impaired regulation of insulin, blood sugar, and cholesterol, as well as abnormal heart function [4].

The BMI provides a good estimate of body fat, and it's more accurate than skin fold measurements. Although the BMI is the official standard, it has several flaws. As the highly trained athletes with big muscles can have BMIs of 30, with little body fat. On the other hand, the BMI may fail to accurately reflect body fatness in adults who have lost substantial amounts of muscle mass. But the most important problem is that the BMI reflects total body fat without regard to how the fat is distributed [5].

Waist Hip Ratio (WHR) is not used only to measure of abdominal obesity. Assessing Waist Circumference (WC) is also very useful, and sometimes more reliable. Both the WC and the WHR have their individual strengths and weaknesses and both are usually measured in a clinical evaluation. Measuring the waist circumference to find out your level of risk, it is important to measure your waist circumference accurately [6]

The Body Fat Percentage (BFP) of a human or other living being is the total mass of fat divided by total body mass, times 100; body fat includes essential body fat and storage body fat. Essential body fat is necessary to maintain life and reproductive functions. The percentage of essential body fat for women is greater than that for men, due to the demands of childbearing and other hormonal functions. The percentage of essential fat is $2-5 \%$ in men, and 10-13\% in women. Storage body fat consists of fat accumulation in adipose tissue, part of which protects internal organs in the chest and abdomen. The minimum recommended total body fat percentage exceeds the essential fat percentage value reported above. A number of methods are available for determining body fat percentage, such as measurement with calipers or through the use of bioelectrical impedance analysis [7].
Diet, exercise, and behavioral modification should be included in all obesity management approaches for Body Mass Index (BMI) of $25 \mathrm{~kg} / \mathrm{m} 2$ or higher. Other tools, such as pharmacotherapy for BMI of $27 \mathrm{~kg} / \mathrm{m} 2$ or higher with co morbidity or BMI over $30 \mathrm{~kg} / \mathrm{m} 2$ and bariatric surgery for BMI of $35 \mathrm{~kg} / \mathrm{m} 2$ with co morbidity or BMI over $40 \mathrm{~kg} / \mathrm{m} 2$, should be used as adjuncts to behavioral modification to reduce food intake and increase physical activity when this is possible [8]

Invasive body-contouring refers to the surgical removal of localized areas of adiposity from under the skin. Liposuction is the most common cosmetic plastic surgery procedure used around the world. However, this popular method still raises serious concerns about the safety of its invasive nature. Possible complications, resulting from the invasive procedure, range in severity from prolonged swelling, bruising, and numbness, to thrombophlebitis and pulmonary embolism. A pressing need for safer procedures, with faster recovery time, as well as smaller number of side effects, therefore, makes non-invasive body contouring techniques perhaps several of the most appealing and fastest growing extents of esthetic surgery today. Focused ultrasound, cryolipolysis, radiofrequency and low level laser therapy are among these non-invasive methods, which have gained popularity over the last decade [9]

Ultrasonic Cavitation (UC) is a low frequency, high energy level Ultrasound (US) that induces physical effects on tissues and has recently been proposed as a method to non-invasively reduce the amount of adipose tissue with the rising demand for body contouring, noninvasive devices for fat reduction have become increasing global popular and have grown over the past decade [10]

Ultrasonic waves create compression cycles that exert positive pressure, and expansion cycles that exert negative pressure. This pushing and pulling effect can prompt the cracking of fat cells. Ultrasonic energy into the deeper fat layers can prompt cavities in the fat and theoretically decrease the overall thickness of the adipose layer. The mechanical acoustic effects of ultrasound cavitations caused selective fat cell disruption without injury to skin, vessels, nerves or connective tissue, after disturbance of the fat cells, the substances, principally triglycerides, are scattered into interstitial space and afterwards transported through the vascular lymphatic framework to the liver. These triglycerides are hypothetically retained gradually and after that are metabolized by endogenous lipases to glycerol and free unsaturated fats [11] 
Cryolipolysis is approved by Health Canada and the U.S. Food and Drug Administration (FDA) for the reduction of focal adiposity. Cryolipolysis called "energy extraction," is the controlled application of cold to subcutaneous tissue to reduce adipose tissue. The procedure can be performed by any physician on an outpatient basis without anesthesia or analgesia. When cryolipolysis is performed, suction is used to draw the target tissue into a cup-shaped applicator, in which contact is established between the treatment area and two opposing cooling panels. Additional studies in both animals and humans suggest that cryolipolysis has little or no effect on tissues adjacent to the treatment zone, including nerve bundles. The destruction of adipocytes does not significantly affect serum lipid levels or liver function tests [12].

\section{Subjects and Methods}

\section{1- Subjects:}

Thirty patients of both sexes with Central Obesity aging from 45-55 years old. They were selected from Abou El-Nomros Central Hospital, GizaEgypt. All patients were investigated and diagnosed by internal medicine doctor. They were received this treatment program during 2017 and randomly assigned into two equal groups, group (A), and group (B).

- Group (A): It included 15 patients who was received Ultrasound Cavitation treatment program for 30 days (8 sessions/patient).

- Group (B): It included 15 patients who was received Cryolipolysis treatment program for 30 days (one session/patient).

Inclusion criteria: All patients were diagnosed clinically with central obesity as waist circumference > $102 \mathrm{~cm}$ in men \& $88 \mathrm{~cm}$ in women and BMI $>25 \mathrm{~kg} / \mathrm{m}^{2}$.

Exclusion criteria: Patients with these diseases were excluded from the study: Cancer, renal failure patients, hemiplegia, parkinsonism, fractures of extremities and respiratory diseases.

Randomization: The participants were randomly assigned to group (A) $(n=15)$ or group $(B)(n=15)$ by an independent person who selected blindly from sealed envelopes containing numbers created by a random number generator. The randomization was restricted to permuted blocks to ensure that equal numbers were allocated to each group $\mathrm{A}$ and group B. The sequences assigned to the participants were placed in envelopes containing the allocation to each group A and group B.
The aim and procedures of the study were informed to eligible patients. All patients signed a written informed consent. The study was approved by the Ethical Committee of Faculty of Physical Therapy, Cairo University.

Evaluation: Every patient was assessed by a physician to select eligible patients. Before patient inclusion in this study, a complete medical history and drug history were used for the patients. All tests were performed before the sessions (pre-) and after (post-) sessions period for each participant including Body Mass Index (BMI), Waist Circumference (WC) and Abdominal Fat Percentage (AF\%). To control the acute effects of Ultrasound Cavitation and cryolipolysis on central obesity, all final results was measured at one month after the starting of the treatment sessions.

- Body Mass Index (BMI): Measured by Tanita device (made in Japan) is advanced bioelectric impedance analysis or calculated by weight in $\mathrm{Kg}$ divided by height in $\mathrm{m}^{2}\left(\mathrm{Kg} / \mathrm{m}^{2}\right)$.

- Waist Circumference (WC): Measured by tap measurement at the mid abdominal level (umbilical level).

- Abdominal Fat Percentage (AFP\%): Measured by Tanita device (made in Japan) is advanced bioelectric impedance analysis.

\section{Treatment procedures:}

1- Ultrasound cavitation: Ultracav 2100 (made in Italy) Medical cavitation was used in this study, each patient of group A were treated using ultrasound cavitation as following: Patients lies in supine position with the right and left side free, cavitation hand piece applied at the abdomen after putting ultrasonic gel needed (medium), the device frequency sited according to fat accumulation thickness (fat layers), circular and regular movements of the hand piece over the treatment site applied, the duration of the treatment session was 20 minutes and each patient received 8 sessions with 3 days intervals between each one ( 2 sessions/week).

2- Cryolipolysis: Laser 2 Handles Cryo Therapy Machine H3007 (made in China) was used in this study, each patients of group B were treated using Cryolipolysis as following: The head of the device applied on the abdomen area, the device suction started and the temperature of the abdomen decreased without affecting the rest of body, session time $45 \mathrm{~min}$, this procedure caused unwanted fat cells to freeze and subsequently die and each patient received one session per month. 


\section{Statistical analysis:}

Results are expressed as mean \pm standard deviation or number (\%). Test of normality, KolmogorovSmirnov test, was used to measure the distribution of data. Accordingly, comparison between variables in the two groups was performed using unpaired $t$ test. Comparison between variables measured preand post-treatment in the same group was performed using paired $t$-test. Percent change was calculated from equation: [(Pre-post)/ pre] X 100 or vise versa whenever it was appropriate. Statistical Package for Social Sciences (SPSS) computer program (Version 19 windows) was used for data analysis. $p$ value $\leq 0.05$ was considered significant.

\section{Results}

This study suggested that significance reduction of central obesity (BMI, abdominal Fat $\%$ and WC) after performing ultrasound cavitation and cryolipolysis sessions in patients with central obesity. For group A (ultrasound cavitation), percentage of improvement $\downarrow$ of BMI was $2.94 \% \downarrow$, abdominal fat $\%$ was $11.07 \% \downarrow$ and WC was $5.59 \% \downarrow$. For group B (Cryolipolysis), percentage of improvement $\downarrow$ of BMI was 3.62\% $\downarrow$, abdominal fat $\%$ was $19.11 \% \downarrow$ and WC was $4.68 \% \downarrow$. But there were non statistical significance difference between both groups at means of central obesity (BMI, abdominal fat $\%$ and $\mathrm{WC}$ ) after performing ultrasound cavitation and cryolipolysis sessions in patients with central obesity.

Table (1): General (physical) characteristics of the two studied group.

\begin{tabular}{lllll}
\hline & $\begin{array}{c}\text { Group A } \\
(\mathrm{n}=15)\end{array}$ & $\begin{array}{c}\text { Group B } \\
(\mathrm{n}=15)\end{array}$ & $\begin{array}{c}t- \\
\text { value }\end{array}$ & $\begin{array}{c}p \text { - } \\
\text { value }\end{array}$ \\
\hline $\begin{array}{lllll}\text { Age (yrs.): } \\
\text { Min.max. }\end{array}$ & $\begin{array}{l}45-55 \\
50.47 \pm 3.31\end{array}$ & $\begin{array}{l}45-55 \\
49.47 \pm 3.89\end{array}$ & 0.758 & $\begin{array}{l}0.455 \\
\text { NS })\end{array}$ \\
Mean \pm SD & & & & \\
Gender: & & & & \\
Female & $7(46.7 \%)$ & $8(53.3 \%)$ & $\chi^{2}=$ & 0.715 \\
Male & $8(53.3 \%)$ & $7(46.7 \%)$ & 0.133 & $(\mathrm{NS})$ \\
\hline
\end{tabular}

Data are expressed as mean \pm SD or number $(\%)$.

$\chi 2=$ Chi square test. $\quad \mathrm{NS}=p>0.05=$ not significant

Table (2): Intra-and inter-group comparison between mean values of BMI in the two studied groups measured pre-and post-treatment.

\begin{tabular}{lllll}
\hline & $\begin{array}{c}\text { Group A } \\
(\mathrm{n}=15)\end{array}$ & $\begin{array}{c}\text { Group B } \\
(\mathrm{n}=15)\end{array}$ & $\begin{array}{c}t \text { - } \\
\text { value\# }\end{array}$ & $\begin{array}{c}p \text { - } \\
\text { value }\end{array}$ \\
\hline Pre-treatment & $36.69 \pm 3.94$ & $35.61 \pm 3.09$ & 0.841 & $0.408(\mathrm{NS})$ \\
Post-treatment & $35.61 \pm 3.86$ & $34.32 \pm 2.96$ & 1.030 & $0.312(\mathrm{NS})$ \\
Mean difference & 1.08 & 1.29 & & \\
\% change & $2.94 \downarrow \downarrow$ & $3.62 \downarrow \downarrow$ & & \\
$t$-value\#\# & 18.924 & 24.125 & & \\
$p$-value & $0.001(\mathrm{~S})$ & $0.001(\mathrm{~S})$ & & \\
\hline
\end{tabular}

Data are expressed as mean $\pm \mathrm{SD}$. $t$-value\#= unpaired $t$-test.

$\mathrm{NS}=p>0.05=$ not significant.

$\mathrm{S}=p<0.05=$ significant.

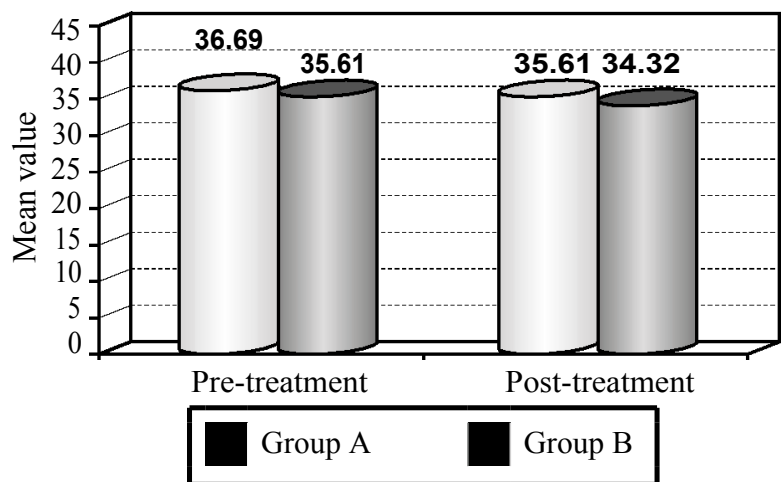

Fig. (1): Comparison between mean values of BMI in the two studied groups measured pre-and post-treatment.

Table (3): Intra-and inter-group comparison between mean values of abdominal fat percent in the two studied groups measured pre-and post-treatment.

\begin{tabular}{lllll}
\hline & $\begin{array}{c}\text { Group A } \\
(\mathrm{n}=15)\end{array}$ & $\begin{array}{c}\text { Group B } \\
(\mathrm{n}=15)\end{array}$ & $\begin{array}{c}t \text { - } \\
\text { value\# }\end{array}$ & $\begin{array}{c}p \text { - } \\
\text { value }\end{array}$ \\
\hline Pre-treatment & $31.70 \pm 6.99$ & $28.83 \pm 6.50$ & 1.165 & $0.254(\mathrm{NS})$ \\
Post-treatment & $28.19 \pm 7.99$ & $23.32 \pm 6.93$ & 1.785 & $0.085(\mathrm{NS})$ \\
Mean difference & 3.51 & 5.51 & & \\
$\%$ change & $11.07 \downarrow \downarrow$ & $19.11 \downarrow \downarrow$ & & \\
$t$-value\#\# & 8.392 & 7.366 & & \\
$p$-value & $0.001(\mathrm{~S})$ & $0.001(\mathrm{~S})$ & & \\
\hline
\end{tabular}

Data are expressed as mean $\pm \mathrm{SD}$.

$t$-value\#= unpaired $t$-test $\mathrm{NS}=p>0.05=$ not significant. $t$-value\#\#= paired $t$-test.

$\mathrm{S}=p<0.05=$ significant

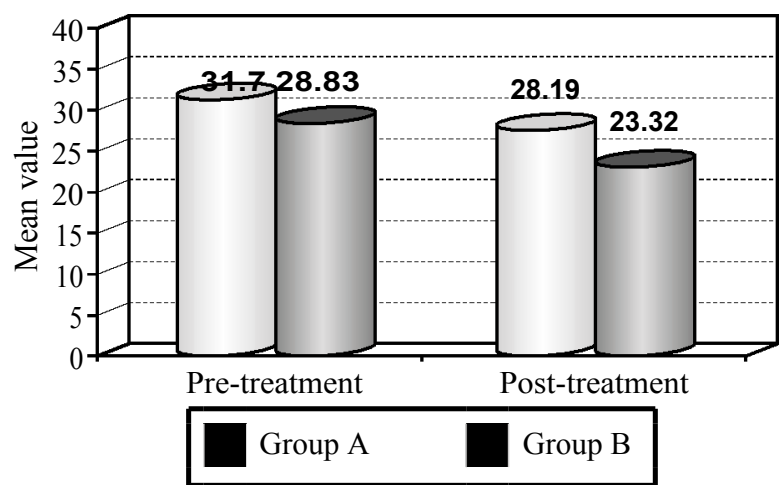

Fig. (2): Comparison between mean values of abdominal fat percent in the two studied groups measured pre-and post-treatment.

Table (4): Intra-and inter-group comparison between mean values of waist circumference in the two studied groups measured pre-and post-treatment.

\begin{tabular}{|c|c|c|c|c|}
\hline & $\begin{array}{c}\text { Group A } \\
(\mathrm{n}=15)\end{array}$ & $\begin{array}{c}\text { Group B } \\
(\mathrm{n}=15)\end{array}$ & $\begin{array}{c}t- \\
\text { value\# }\end{array}$ & $\begin{array}{c}p- \\
\text { value }\end{array}$ \\
\hline Pre-treatment & $108.60 \pm 15.93$ & $110.33 \pm 9.68$ & -0.360 & $\begin{array}{l}0.722 \\
\text { (NS) }\end{array}$ \\
\hline Post-treatment & $102.53 \pm 16.21$ & $105.17 \pm 10.02$ & -0.535 & $\begin{array}{l}0.598 \\
\text { (NS) }\end{array}$ \\
\hline $\begin{array}{l}\text { Mean difference } \\
\% \text { change } \\
t \text {-value\#\# } \\
p \text {-value }\end{array}$ & $\begin{array}{l}6.07 \\
5.59 \downarrow \downarrow \\
39.581 \\
0.001(\mathrm{~S})\end{array}$ & $\begin{array}{l}5.16 \\
4.68 \downarrow \downarrow \\
18.816 \\
0.001(\mathrm{~S})\end{array}$ & & \\
\hline
\end{tabular}

Data are expressed as mean \pm SD. $\quad t$-value\#= unpaired $t$-test. $\mathrm{NS}=p>0.05=$ not significant. $\quad t$-value\#\#= paired $t$-test.

$\mathrm{S}=p<0.05=$ significant 


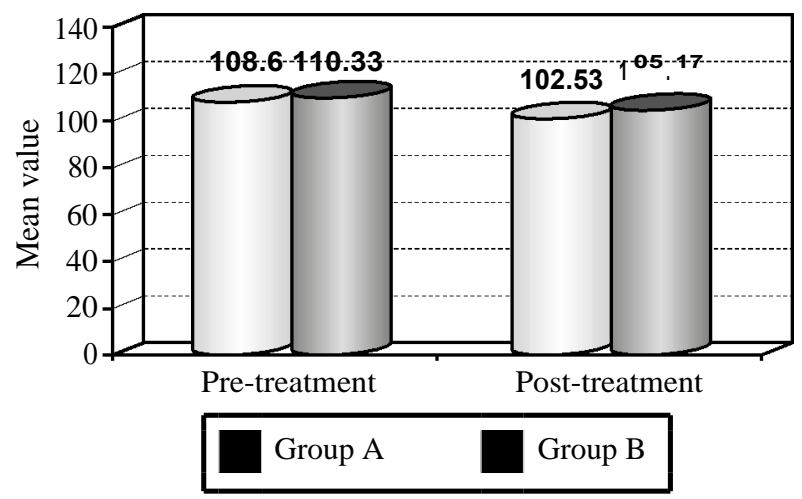

Fig. (3): Comparison between mean value of waist circumference in the two studied groups measured pre-and post-treatment.

\section{Discussion}

The objective of this study was to determine the effect of ultrasound cavitation and cryolipolysis on central obesity. This study found that there was decrease in abdominal fat in both Group A and Group B after applying ultrasound cavitation and cryolipolysis sessions but the improvement in Group B is little more than that in Group A.

This study was conducted on 30 central obese subjects (15 men and 15 women) who were volunteered to participate in the study, their ages ranged from 45 to 55 years, and they were selected from "Abou El-Nomros Central Hospital".

The patients were assigned into two groups equal in number: The first group (Group A), consisted of 15 patients, who underwent an ultrasound cavitation sessions. The Second group (Group B), consisted of 15 patients, who underwent a cryolipolysis sessions.

The following measurements were done for both groups: Body mass index, abdominal fat percentage, waist circumference. These variables were measured initially before starting the treatment and after the end of the sessions in both groups. The study duration was one month.

The analysis of the results can be divided into two main points:

- The first point of analysis was the effect of ultrasound cavitation sessions on central obesity, Group A: Analysis of the results of the present study revealed that ultrasound cavitation sessions program had a positive effect on central obesity (BMI, abdominal fat\% and WC). The percentage of improvement for BMI, abdominal fat $\%$ and WC was $2.94 \% \downarrow, 11.07 \% \downarrow$ and $5.59 \% \downarrow$ respectively.
- The second point of analysis was the effect of cryolipolysis sessions on central obesity, Group B: Analysis of the results of the present study revealed that cryolipolysis sessions program had a positive effect on central obesity (BMI, abdomial fat $\%$ and WC). The percentage of improvement for BMI, abdominal fat $\%$ and WC was $3.62 \% \downarrow$ $19.11 \% \downarrow$ and $4.68 \% \downarrow$ respectively.

The results obtained in the present investigation also indicated that there was non significant differences between mean differences BMI, abdominal fat $\%$ and WC of both Groups (A and B) $(p>0.05)$ by using independent $t$-test, but there was higher percentage of change (more positive effect) in Group B than Group A.

The results of this study came in agreement with the study of Mulholland et al., [13] who demonstrated that the Ultrasound cavitation and Cryolipolysis are effective, safe, and well tolerated non-invasive procedures for the reduction of fat thickness in the abdominal region. Both techniques produced nearly equal reduction in waist circumference and skin folds, and both can be used for body contouring.

Also, El-Desoky et al., [14] demonstrates that clinical study showed that both ultrasound cavitation and cryolipolysis systems are safe and effective for body contouring and for decreasing abdominal adiposity. Both significantly reduced excess subcutaneous adipose tissue from the abdomen, as reflected by the decrease in participants' waist circumference and skinfold measurements. There was no significant difference between the two techniques with regard to the reduction of fat thickness.

Also, High Intensity Focused Ultrasound (HIFU) was initially developed to treat medical conditions such as kidney stones and uterine fibroids often times avoiding the need for more aggressive surgical measures. In a patient safety study, no abnormalities in lipids, inflammatory markers or renal and hepatic function were identified after treatment with HIFU. A single HIFU treatment with total fluence of $150-165 \mathrm{~J} / \mathrm{cm}^{2}$ reduced waist circumference by $2.1 \mathrm{~cm}$ at 12 weeks post-treatment, The range of fluence per pass was $30-55 \mathrm{~J} / \mathrm{cm}^{2}$ This wide range can be attributed to the need to adjust for the variable degree of pain experienced during treatment [15]

Moreover, Moraga et al., [16] demonstrated that this system was designed to use mechanical (nonthermal) energy to disrupt fat cells, all patients showed significant reduction in subcutaneous fat 
thickness within the treated area. The mean reduction in fat thickness after three treatments was 2.28 $\pm 0.80 \mathrm{~cm}$. Circumference was reduced by a mean of $3.95 \pm 1.99 \mathrm{~cm}$ and without damaging neighboring structures (skin, blood, and lymph vessels, muscles, and nerves), due to their differential susceptibility to mechanical stresses induced by the ultrasound. No adverse effects were observed.

In addition, Bani et al., [17] found in his study that ultrasound cavitation induced a marked, statistically significant decrease $(23 \%)$ in the size of lipid vacuoles in adipocytes (control: 15,654 \pm 942 $\mathbf{m}^{2}$ cavitation: $11,423 \pm 558 \mathrm{~m}^{2}, \quad<0.001 ; \mathrm{n}=3$ ). Similar findings were obtained by comparison of subcutaneous fat biopsies taken at surgery from sham-or ultrasound-pretreated abdominal skin. In patients 1 and 2 (biopsies were taken 1d after the last ultrasound application), the treatment caused a significant reduction $(-26 \%)$ of the size of adipocyte lipid vacuoles (control: $11.908 \pm 373 \pm \mathrm{m}^{2}$ cavitation: $\left.8637 \pm 530 \quad \mathrm{~m}^{2} \quad<0.001\right)$.

On the other hand, in Cryolipolysis, Noninvasive cooling of subcutaneous fat associated with these devices has been shown to be safe in studies of peripheral nerve function, serum lipid levels, and liver function tests. Initial clinical studies demonstrated efficacy, safety, and patient satisfaction for cryolipolysis of the abdomen and flanks. (Cryolipolysis has been safe and effective for nonsurgical reduction of subcutaneous fat. It has received FDA clearance for treatment of abdomen (2012, K120023) [18]

In addition, Derrick et al., [19] demonstrates that, evaluated cryolipolysis in 67 patients with 192 treatments. Treatment areas included abdomen $(\mathrm{n}=50)$, flank $(\mathrm{n}=23)$ areas included abdomen $(\mathrm{n}=50)$, flank $(\mathrm{n}=23)$, outer thigh $(\mathrm{n}=6)$, inner thigh $(\mathrm{n}=2)$, and medial upper arm $(\mathrm{n}=2)$. One treatment cycle was performed for 60 minutes at each area. Ultrasound measurements were taken before and 2 months after treatment. There was a mean reduction of $25.2 \%$ for all treatment areas. Data for treatments outside of the abdomen and flanks were not presented. There was a mean reduction of $25 \%$ for abdomen.

Also, Cryolipolysis is a non-invasive procedure that effectively destroys and removes stubborn pockets of fat from targeted areas of the body ( $25 \%$ in 1 session) Cryolipo is extremely effective for areas that have not responded to diet and/or exercise. Cold temperatures are able to stimulate brown adipose tissue (brown fat) thermogenesis (heat generation), resulting in calorie burn and weight loss. The ultrasound measurement showed an average decrease of $0.02 \mathrm{~cm}$ in the fat layer thickness and anaverage of $0.60 \mathrm{~cm}$ increase in the fibrous septa thickness. A significant reduction in local tissue fibrosis was observed 30 days after treatment. In this phase, the fat layer thinning presented an average of $0.16 \mathrm{~cm}$ and the thinning of the fibrous septa, $0.50 \mathrm{~cm}$. A discrete return of fibrous tissue was observed 45 days after treatment. There was an average of decrease $0.20 \mathrm{~cm}$ in the fat layer thickness at this stage and an increase of $0.06 \mathrm{~cm}$ in the fibrous septa thickness [20]

Furthermore, clinical studies on Cryolipolysis have shown reduction of fat is between $20 \%$ to $40 \%$. Results will vary on the individual, the thickness of the fat deposits in each area, and the lifestyle maintained after treatment. Those that follow the aftercare advice, will get the best results. This depends on the individual, the fat thickness, and the area treated. Changes happen over a number of weeks, 12 weeks being the estimated time to see the maximum result, although begin to see changes at around 2 weeks. In clinical trials 12 weeks post-treatment, 9 out of 10 people saw an undeniable reduction in the treated area. Each session is up to 45 minutes per area. A study used a three-dimensional camera to evaluate the amount of fat loss after cryolipolysis. Mean fat loss between baseline and the 2-month follow-up visit was $56.2 \pm 25.6 \mathrm{cc}$ on the treated side and $16.6 \pm 17.6 \mathrm{cc}$ on the control side $(p<0.0001)$. Two months posttreatment, the mean difference in fat loss between the treated and untreated sides was 39.6cc [21].

Normally, low temperature $\left(-5^{\circ} \mathrm{C}\right.$ to $\left.-7^{\circ} \mathrm{C}\right)$ is then applied to the area in a controlled process, 'freezing' the localized area for 45-60 minutes. Once the cooling procedure is completed, the fat cells are liberated into the lymphatic system and gradually eliminated by the body's natural metabolic process. Skin isn't damaged, but subcutaneous fat, which is more sensitive to targeted cold, begins a 2 months destruction period after exposure to Cryolipo Fat Freezing. After 8 weeks most clients would lose $2,5-5 \mathrm{~cm}$ per treated area. Usually 1 to 3 treatments are needed depending on the thickness of the resistant fat. Treatments can be repeated at 30 days intervals. It can be used on all skin types and ages [22]

\section{Conclusion:}

There was improvement in central obesity after applying ultrasound cavitation and cryolipolysis sessions with mild better results in cryolipolysis than ultrasound cavitation. 


\section{Acknowledgement:}

We are grateful for the support and cooperation of all patients who participated in this study.

Conflicts of interest: None.

\section{References}

1- MULLIN G.E., CHESKIN L.J. and MATARESE L.E.: Integrative Weight Management: A Guide for Clinicians, CH3:21, by Springer Science \& Business, 2014.

2- HARMON D.E.: Obesity: Easyread Large Bold Edition, CH2: 17-18, 16 th edition, by ReadHowYouWant.com, 2008.

3- KLEIN S.: The case of visceral fat: Argument for the defense, JCI the Journal of clinical investigation, V113 (11): 1530-2, 2004.

4- LAVIE C.J.: The Obesity Paradox: When Thinner Means Sicker and Heavier Means Healthier, CH3: 2-3, by Penguin, 2014.

5- BRAY G.A.: Handbook of Obesity Volume 1: Epidemiology, Etiology, and Physiopathology, Volume 1, CH 6:67, by CRC Press, edition, USA, 2014.

6- SHILS M.E. and SHIKE M.: Modern Nutrition in Health and Disease, 1014, by Lippincott Williams \& Wilkins, 3ed, 2006.

7- KANG J.: Nutrition and Metabolism in Sports, Exercise and Health, CH12:310-311, by Routledge, 2013.

8- MOEN J.: Basic Health Care Series: Obesity, CH4: 1-6, by Alpha ED, 2017.

9- ESTEGHAMATI A., MAZAHERI T. and RAD M.V.: Complementary and Alternative Medicine for the Treatment of Obesity: A Critical Review, INT. Journal endocrinal Metabolic, V13(2), 2015.

10-NADAKI H., HOMAEE H.M. and AZARBAYJANI M.A. A Comparison of the effect of HIIT with and without ultrasonic cavitation on body composition, International Journal of Biology, Pharmacy and Allied Sciences, V4 (7): 953-9, 2015.

11-MELVIN A., SHIFFMAN and ALBERTO Di GIUSEPPE: Liposuction: Principles and Practice, ${ }^{2}$ edition, $\mathrm{CH} 29$ : 330-1, by springer, 2016.
12- JEWELL M.L., SOLISH N.J. and DESILETS C.S.: Noninvasive Body Sculpting Technologies with an Emphasis on High-Intensity Focused Ultrasound, Aesthetic Plastic Surgery Journal, V35 (6), 2011.

13- MULHOLLAND R.S. and PAUL M.D.: Noninvasive Body Contouring with Radiofrequency, Ultrasound, Cryolipolysis, and Low-Level Laser Therapy, Clinics in Plastic Surgery Journal, V38 (3): 503-20, 2011.

14- ELDESOKY M.T., ABUTALEB M.E. and MOUSA M.: Ultrasound cavitation versus cryolipolysis for non-invasive body contouring, Australasian Journal of Dermatology, V 57 (4): 1-4, 2016.

15- CHAN J.C.Y., SHEK S.Y.N., YEUNG C.K. and CHAN H.H.: Efficacy of high-intensity focused ultrasonography for noninvasive body sculpting in Chinese patients, Lasers in Surgery and Medicine, V46 (4), 2014.

16- MORAGA M.J., ALTÉS T.V. and RIQUELME A.M.: Body Contouring by Non-Invasive Transdermal Focused Ultrasound, Lasers in Surgery and Medicine Journal, V39 (4): 315-23, 2007.

17- BANI D., QUATTNINI A. and FRESCHI G.: Histological and Ultrastructural Effects of Ultrasound-induced Cavitation on Human Skin Adipose Tissue, Journal of the American Society of Plastic Surgeons, V 1 (6), 2013.

18- STEVEN W.G. and BACHELOR E.P.: Cryolipolysis Conformable-Surface Applicator for Nonsurgical Fat Reduction in Lateral Thighs, Aesthetic Surgery Journal, V35 (1): 66-71, 2015.

19- DERRICK C.D. and BROYLES J.M.: The Safety and Efficacy of Cryolipolysis: A Systematic Review of Available Literature, Aesthetic Surgery Journal, V35 (7): 8306, 2015.

20- MEYAR P.F., Da SILVA R.M.V., OLIVEIRA G. and De ARAUJO NETO L.G.: Effects of Cryolipolysis on Abdominal Adiposity, Case Report in Dermatological Medicine, V2016 (7), 2016.

21- KRUEGER N., MAI S.V. and LUEBBERDING S.: Cryolipolysis for noninvasive body contouring: Clinical efficacy and patient satisfaction, Clinical Cosmet Investig Dermatol (Devopress), V7: 201-5, 2014.

22- COLEMAN S.R., SACHDEVA K., EGBENT B.M. and ALLISON J.: Clinical Efficacy of Noninvasive Cryolipolysis and Its Effects on Peripheral Nerves, Aesthetic Plastic Surgery, V33 (4): 482-8, 2009. 


\section{تآثير التجويف بالموجات فوق الصوتية مقابل تكسير الدهون بالتجميد على مرضى السمنة الهوتية محابل}

الهدف من الدراسة: دراسة تآتّير التجويف بالموجات فوق الصوتية مقابل تكسير الدهون بالتجميد على مرضى السمنة المركزية. خطة البحث: فى هذه الدراسة ثلاثقن مريضا (10 رجل، 10 سيدة) تم إختيارهم عشوائيا من العيادات الخارجية لمستشفى آبو النمرس

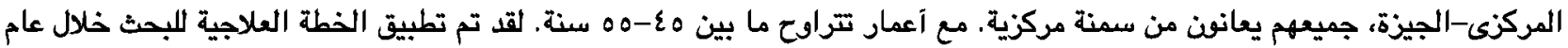

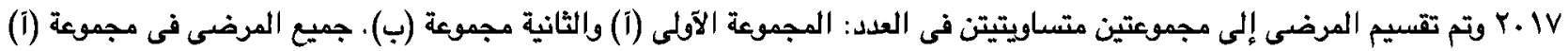

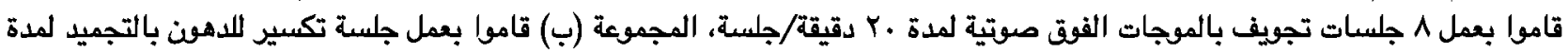

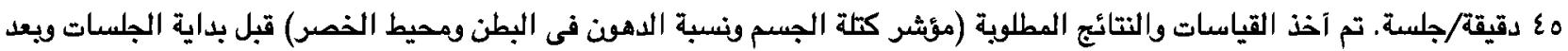
جلسات التجويف بالموجات الفق صوتية وجلسات تكسير الدهون بالتجميد في كل من المجموعتين. نتائج البحث: بمقارنة القياسات المبدئية بالنسبة للنتائج التى تم الحصول عليها، وجدت النتائج كالآتى:

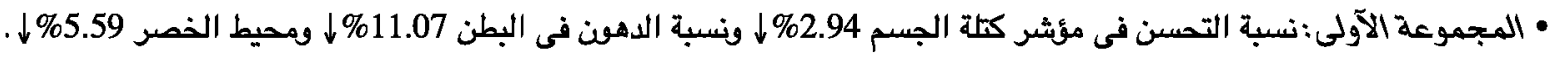

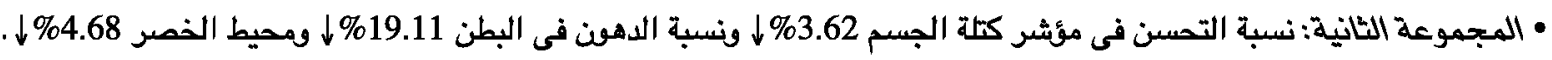
ومن المقارنة بين إنخفاض السمنة المركزية فى المجموعتين نجد الإنخفاض كان آكبر فى المجموعة الثانية (ب) عن المجموعة الآولى (آ) ولكن لا يوجد فروق ذات دلالة إحصائية عالية بين المجموعتين.

وآخيرا هذه الدراسة تؤكن آن كلا من التجويف بالموجات الفوق صوتية وتكسير الدهون بالتجميد له تآثير فعال فى خفض السفي السمنة المركزية

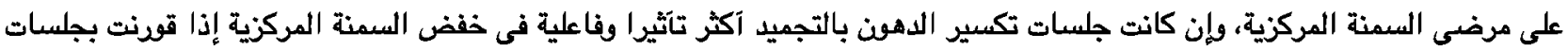

